\title{
An Apartheid of Souls \\ Religious Rationalisation in the Netherlands and Indonesia ${ }^{1}$
}

\author{
ALBERT SCHRAUWERS
}

Described in travel books as a 'sleepy church town', Tentena is unusual in Indonesia, a nation where ninety per cent of the population is Muslim. In Tentena, on the island of Sulawesi, the proportions are reversed. There, as in much of rural Indonesia, religion clearly demarcates distinct ethnic and class boundaries: the majority of ethnic To Pamona, the indigenous peoples of the area, converted to Protestantism under the Netherlands Missionary Society at the turn of the century. Their church synod offices dominate the town. Largely peasant farmers, the To Pamona are culturally, religiously and economically distinguishable from both the Muslim Bugis traders who live around the market quarter, and from the ethnic Chinese Pentecostal merchants whose large shops dominate the local economy. This confluence of religion and ethnic identity among the To Pamona was fostered by Dutch missionaries who sought to create a 'people's church' or volkskerk, of the sort they were familiar with in the Netherlands. ${ }^{2}$ Driven by a new respect for indigenous cultures, the missions relativised the church's tenets; they argued that different 'nations' like the To Pamona could have their cultures preserved within their 'national' churches as long as those traditions were evaluated from a Biblical perspective. ${ }^{3}$ This discourse on 'culture', and missions in the vernacular, created a 'nationalist' religious discourse among the To Pamona infused with the 'emancipatory' politics of the churches in the Netherlands. ${ }^{4}$ The product of these strategies of incorporation was the religious 'pillarization' of the peoples of the highlands of Central Sulawesi, and their division into socially autonomous ethno-religious blocks.

When the To Pamona were being missionised at the turn of the century, Dutch society was similarly 'pillarized' (Dutch verzuild) by religion, a less wellknown metaphor than apartheid which it resembles in spirit. 'Pillarization' refers to the religious apartheid which characterised the Netherlands in the first half of the century. Orthodox Protestants and Catholics hindered the development of a universal secular state and created a plural administration on a religious basis. ${ }^{5}$ These institutionalised religious 'pillars' were composed of religious school systems, religious political parties, and a host of religiously oriented service agencies such as housing developments, unions, newspapers, 
hospitals, etc. to serve their members 'religious' needs. Secularism, as an ideology, was marginalised. A typical 'pillarized' citizen would, for example, rent a house in a Protestant-church sponsored housing development, send their children to a church sponsored school, read Protestant newspapers, and vote for the Orthodox Calvinist 'Anti-Revolutionary Party'.

It is in the light of the Dutch historical case that the social cleavages of Tentena should be examined. To Pamonan ethnic identity is fostered by a church-run school system, hospital, and women's, men's and youth worship groups. They were also represented by their own Protestant political party, the Partai Kristen Indonesia or Parkindo. Muslims in the village similarly sponsor their own religious school system, charitable organisations and political party. Placed against the Dutch background of societal divisions, the postindependence development of these socio-religious pillars in Indonesia appears less exotic and more an effect of colonial intervention. The Javanese studied by Clifford Geertz during the short-lived democratic period referred to these pillars as aliran, 'streams'. The brand of secular nationalism upon which Indonesia's first president, Sukarno, had based the republic received little support in Sulawesi, and aliran appear even more pronounced in Sulawesi than in Java where the term originated. ${ }^{6}$ While the similarity between the Dutch and Indonesian cases has been noted in the past, it has been treated descriptively, rather than analytically, resulting in the general view that they have disappeared along with the Communist party in the political reorganisation which followed Suharto's rise to power after 1965.' However, if we view these pillars as the product of 'religious rationalization' their marginalisation is not as evident. Their effective persistence leads to questions about the role they will play as Indonesia makes tentative moves towards greater democratisation. ${ }^{8}$

Central Sulawesi is an ethnically diverse province; its population of slightly less than two million people is divided among five major language families, and twenty-five different languages. ${ }^{9}$ The mountainous topography and incipient warfare found throughout the island at the turn of the century precluded the formation of any widespread regional identities; 'ethnic identity', if it can be labeled such, was linked to the kinship ties which bound the various hamlets within the confluence of a river together into loosely knit confederacies. These amorphous groups lacked established regional leadership roles, and rarely acted as a unit. The situation was similar to that which Henley describes for early nineteenth century Minahasa; the To Pamona also consisted of a sizable group of communities which shared some basic cultural patterns, recognised a common genealogical origin, and expressed their unity in the sphere of ritual and religious belief. The cultural emphasis, however, was upon systematic and complementary differences rather than upon homogeneity and solidarity, and the ethnic group as a whole had no name. ${ }^{10}$

Although the Netherlands East Indies (hereafter NEI) government had signed a number of political treaties with the various kingdoms on the coast of the Bay of Tomini, its control of the interior of the island was non-existent, ham- 
pered by its policy of 'abstention' in the Outer Islands. This situation changed at the turn of the century with a renewed Dutch imperialism, the 'rounding off of empire'." As Dutch corporations increasingly turned to the Outer Islands as sources of natural resources, the NEI government was pushed to more firmly establish rule over its hinterlands. ${ }^{12}$ Lacking the manpower to establish a post in Central Sulawesi, the Assistant-Resident of North Sulawesi sought a temporary solution in the Netherlands Missionary Society (Nederlandsch Zendeling Genootschap, hereafter NZG). The establishment of a mission post would serve a dual function; first, it would establish actual Dutch occupation of the territory, and hence a Dutch eye for interlopers. And second, the mission would actively work to stem the growing influence of Islam and the indigenous states in the highlands. Albert C. Kruyt established a mission post at Poso in 1892. ${ }^{13} \mathrm{He}$ was soon aided by Dr Nicolaüs Adriani, of the Netherlands Bible Society (Nederlandsch Bijbelgenootschap) in 1895.

These two men, each from a strong mission background, embody the new religious currents affecting missions in the Netherlands East Indies in the age of 'pillarization' in the Netherlands. Initially, their mission was spectacularly unsuccessful (no convert was made until 1910); hence both men devoted a great deal of their energies to 'scientific' pursuits. Ethical Theology and Ethical Policy were combined in these men to produce a new mission methodology, the 'Sociological Method', in which ethnography and language study played a key role. Between them, Kruyt and Adriani produced no less than four lengthy ethnographies of the 'East Toraja', ${ }^{14}$ theoretical studies on 'animism', 15 two dictionaries, ${ }^{16}$ an extensive grammar, ${ }^{17}$ as well as articles too numerous to mention. ${ }^{18}$ This flood of information about the previously unknown 'Toraja' provided a showcase for the new missiological method which became a standard for the next generation of missionaries.

But Kruyt and Adriani's influence in fostering an eventual To Pamona ethnic consciousness went beyond their analytic definitions of the territorial boundaries of this group; they were also crucial, through their mission, in establishing the specific religious content of this ethnic identity over the course of the twentieth century. Kruyt's 'sociological' method was a practical application of Ethical Theology. Ethical Theology conceptualised the role of the church in terms of a spiritual community, the volkskerk, a concept which grew out of the distinction between Christianity and culture, Christianity being universal, and cultures specific. The sociological method was thus a means of 'acculturating' Christianity within a non-Christian people in such a way that their culture was Christianised without necessarily losing its distinctive ethos. This concern to acculturate Christianity sprang from the revivalist emphasis on the emotional bond between the believer and God; personal piety could only emerge where Christianity was not perceived as an alien imposition. Kruyt's tolerance for the adat of the To Pamona was very much in keeping with the new emphasis put on the preservation of adat law in colonial government circles. 
How must we approach the adat? When we truly recognize the adat as the form wherein the Indonesian shows his inner being, when we view the adat as the result of a perhaps age old history and development, if we know that the adat is the formulation of the most appropriate rules of living for the people, then we stand with respect towards the adat, even if it does differ from our opinions. Then we will study it to understand how it works, and that which people cannot retain as Christians we do not cut off in rough fashion, but rework the thoughts and feelings of the native Christian through preaching the Gospel, through Christian education, so that whenever their circumstances have changed, become Christian, they themselves will alter their adat, so that they in their Christian state, become an expression of what lives within them. Only then will the double-sidedness of their being of which I spoke, be left behind. ${ }^{19}$

The sociological method involved a process of ethnographic study, followed by the selective utilisation and reworking of indigenous rituals within the framework established by the mission. Kruyt recognised that the message of the gospel was not self-evident and that Indonesian converts often interpreted his message in their own cultural terms. Kruyt saw such attempts as encouraging, as a sign that converts were seeking to find the relevance of the gospels within their cultures. He did not view conversion as an all-or-none individual phenomenon, but as a developmental process in which a culture was Christianised, thus providing a supportive social context for individual piety. This process was characterised by preaching the gospel, its reception and the evocation of questions about its application in their lives, followed by the selective reworking of the adat by Indonesians themselves. Kruyt refused to issue a set of rules; he insisted on the reformation of the old adat through a dialogue with the mission. ${ }^{20}$ The end product would not be the secular adat sought by the NEI state - a set of customary laws through which they could rule - but a 'Christian adat' by which a new volk, the To Pamona, would come to recognise themselves.

It was, however, this attempt to Christianise the adat which engaged the church in politically volatile relations with the NEI state about the boundaries of 'religion' in the colony. The 'To Pamona' had no word for religion, and adat served as both religious and civil code. The NEI state was predicated upon indirect rule through customary law, the same adat which the missionaries were seeking to change and control. The Binnenlands Bestuur, the civil bureaucracy, required the abstraction of 'religion' from adat so that 'adat law' would be applied in 'civil' matters only. Religious freedom was to be guaranteed, and converts spared from persecution under adat law by nonChristian headmen, district chiefs and the newly imposed raja (local king).

As already noted, the appropriate division of state and religious spheres was a contentious issue within Dutch society itself, and not one easily resolved when applied in the colonial context. The paternalistic bias of both the Nether- 
lands East Indies government and the missions ensured that the definitions of adat law and religion would lie in Dutch hands:

To mix in the affairs of a people a fixed program is required wherein the one thing is allowed, the other not which is primarily a political matter and thus not something offered with free choice. Only knowledge of a people, and love for a people give insight in that which we may interfere in [...] We cannot know beforehand what a people really needs, but we can discover it. This applies to both civil servants as well as missionaries, and the best service they can offer each other is to stand by each other in the search for that which they still need to become good leaders of the people who are entrusted in their care. ${ }^{21}$

This political process was muddied, however, by the fact the two parties did not share the colonial state's liberal assumptions about the role of religion. Even Adriani, who the other missionaries regarded with some suspicion as too close to the state (he came from an elite, liberal family) nevertheless argued that no matter where the line was drawn, the civil code must also be consistent with Christian values and practice.

By Christian adat we mean both the civil as well as the religious adat. We don't pull the civil adat within the sphere of religion, but leave it as large a terrain as possible. Both are to be viewed as the Christian adat. Out of this observation it follows that the civil and religious adat cannot conflict with each other. The one must be called Christian as much as the other. ${ }^{22}$

The mission was relatively more successful than the NEI state in establishing its 'Christian adat' and hence in making religion one of the primary ethnic markers of the new To Pamona volk. I turn now to the institutional processes that supported the creation of To Pamona ethnicity, and that provided it with a political forum within which local elites could renegotiate the meaning of local 'culture'.

Kruyt's mission expanded rapidly after the colonial incorporation of the highlands in 1905; mass conversions followed the colonial state's banning of the primary animist rituals of headhunting, and the secondary reburial of the dead. The introduction of wet-rice cultivation also made the rituals associated with slash-and-burn agriculture redundant. Tentena, an amalgamation of six hamlets, had a substantial Christian community by 1920 . The minister of the local church was Kruyt's adopted To Pamona son, Pancali Sigilipu. When the mission church established an independent synod in 1947, the synod offices were established in Tentena with Jan Kruyt, another son, as chair. ${ }^{23}$ It is then, within this church bureaucracy that the negotiation of To Pamona ethnic identity took place, and the institutional requirements for the 'pillarization' of highland society were provided.

The relative success of the mission in defining local ethnic identity derives from the means by which it incorporated local kinship elites within its Presbyte- 
rial structure. The mission, striving to acquire voluntary 'converts', was forced to work within the limits of traditional forms of social organisation. Kruyt had noted as early as 1912, that the leaders, or kabosenya, of extended kinship groups who dominated the consultative hamlet council (wa'a ngkabosenya) needed to be incorporated within the church since they were already taking charge of the organisation of most church festivities. ${ }^{24}$ However, at that time not all members of the village council were Christian, hence its members could not automatically assume the status of church Elders, even if, as was the case, they were arranging Christian events for their Christian neighbours: As a result, Kruyt institutionalised the role of Elder without institutionalising a decision-making consistory (which informally remained the unrecognised consultative hamlet council). The Elder, like the kabosenya of old, was consensually selected by the villagers (both Christians and non-Christians).

These Elders were considered church headmen, a role paralleling that of the village headman appointed by the colonial government. ${ }^{25}$ An early Pamonan teacher in Tentena, L. Molindo, stated that this proved a consistent problem for villagers in distinguishing the sphere of competence of church from state. The missions emphasised that the role of Elder was more like that of the traditional, non-coercive kabosenya, rather than the appointed village headman. Although a church leader and organiser, the Elder was not a decision-maker as decision-making was still the function of the village council, the provisional Consistory advised by the mission teacher-preacher. In Tentena, an Elder was selected for each of the original six-hilltop hamlets. Each of these Elders preached weekly to the members of their hamlet, now officially designated an 'Evangelisation Group' by the mission. The Evangelisation Groups thus served to perpetuate the boundaries and kin-linked leadership of these hamlet groups within the village of Tentena as a whole.

The relations of authority and dependence created through kinship thus influenced the effectiveness of the Evangelisation Group. These kinship relationships were maintained through a series of exchanges which made the holding of ritual feasts possible. Feasts, in turn, were the means by which political status was asserted. Through the Evangelisation Group structure, these traditional feasts were melded to the Presbyterial structure of the mission church. Such linkages between a 'universal' religion and a local feasting tradition can also be seen in the selametan which plays a similar role among the Muslim Javanese. ${ }^{26}$ The Javanese comparison is intended to underscore the point that such 'borrowings' are not indicative of 'incomplete conversion' or syncretism. Woodward argues, "it is impossible to evaluate the "Muslimness" or "Hinduness" or "Christianness" of a local tradition unless the analysis of local custom and ritual is informed by knowledge of the textual tradition in question'. ${ }^{27}$ He ably demonstrates how the Javanese selametan is rooted in local interpretations of Sufi (rather than modernist) doctrine.

The Evangelisation Group service, at its most basic, is a formal worship service hosted by households on a rotating basis, after which coffee and cakes are served. The commensal eating of even the most basic of foods designates 
the participants as living in harmony (mosintuwu). The larger the feast, the greater the fellowship. Many families take advantage of their turn to host the group as an opportunity for a Thanksgiving service. The Thanksgiving service may be held for many reasons: a birthday, a successful harvest, graduation, the cure of an illness, etc. The Thanksgiving service is also an expression of a household's ability to feast, of its prosperity. The form of the Thanksgiving service is similar to a regular religious service, except that the food offered is correspondingly luxurious. Indeed, meat is rarely eaten except at such events. The expense of even the smallest Thanksgiving service is often out of bounds for the poorest families but social pressure is so intense that everyone will attempt to host at least one.

The Evangelisation Groups were linked to the larger Presbyterian structure of the mission church by indigenous teacher-preachers who served as culture brokers. Their power derived from their influence within the mission and the mission's influence on the government in ameliorating the burdens of colonial rule. This initially set the teachers outside the political arenas where traditional leadership held sway. However, as more and more villagers became Christian, and as those traditional political arenas were incorporated within the church, the teacher acquired wider authority. L. Molindo, Pancali Sigilipu's replacement, related how he served not only as teacher and preacher, but was called upon to settle disputes and arbitrate on matters of the new 'Christian adat'.

It was among this group of well-educated mission and government workers, not the 'traditionalist' kabosenya, that the church's nationalist discourse, its conception of a volk, and of a volkskerk, took root. Competing with the bettereducated Menadonese teachers who preceded them, they could justify their preferential access to mission and government jobs only in terms of an indigenous discourse; 'their' language and 'their' adat were the fundament of Dutch rule. These men were regularly moved throughout the district, and thus derived their authority from their bureaucratic roles, not their kinship ties. By rooting their authority in Dutch institutions predicated upon territorially bounded 'imagined communities' which were said to share a language and culture, they became the first to 'recognize' the 'reality' of Kruyt's ethnic prescriptions. That is, with their own authority rooted in Dutch sponsored 'nationalist' projects, mission and government workers actively supported and helped form the ethnic 'object' which only the Dutch had been able to perceive before. As evangelists, they sought to create the 'brotherhood (ja'i) of Christ' in the highlands. As civil servants they ruled according to the adat prescriptions of Dutch mission and government.

After Indonesian independence, Central Sulawesi was plunged into a period of civil turmoil marked by several regional rebellions which severed its ties with the new Republic. The weakness of the state can be contrasted with the rapid growth of the Christian Church of Central Sulawesi (GKST). The symod was rigorously democratic and thus constituted a viable political organisation that, in the turmoil of the 1950 s, provided for the stable administration of To Pamona villages. This synod assumed control over the mission's schools, 
hospital, churches and personnel. Also incorporated within the new church were the kabosenya who served as Elders, and who utilised their authority to settle disputes at the village level. This stable administrative base served the church well as it sought to protect its interests through a political wing, Parkindo (Partai Kristen Indonesia, the Indonesian Protestant Party) which successfully campaigned in the elections of 1955 (and 1999).

It should by now be clear that from an organisational perspective, the 'To Pamona' have been thoroughly 'pillarized' on a religious basis, much like the Dutch churches from which they emerged. The GKST can be divided into a congregational wing 'inculturated' in a local feasting tradition, and a 'modernist' wing implementing educational, economic and health projects. Both wings articulate at the synodal level, in a modern, rationalising bureaucracy. The church's health and growth is dependent upon its ironic preservation of tradition within a modernising project, a volkskerk.

With the resurgence of the state bureaucracy in the New Order era, many of the overt signs of the 'pillarization' of To Pamona society have been weakened. The New Order government did not consider itself a 'secular' state; the first principle of the constitution, or Pancasila, bases the rule of the state on monotheism. The New Order has interpreted this principle to mean state support and regulation of monotheistic religions (agama) through the financial support of mosque and church building, mandatory religious education in state schools, and a variety of other measures. This attempt to incorporate religious bodies within the state by weakening their independent activities has been accompanied by the enforced elimination of the religious political parties; they were incorporated in secular omnibus parties and forced to abandon their sacred texts as their 'philosophical' basis (asas tunggal). These new parties (the Indonesian Democratic Party PDI and the United Development Party PPP) were forced to acknowledge the ideological principles of New Order rule (the Pancasila) as the sole foundation of their organisations. This emasculation of the 'modern wing' of the church, and the elimination of its political base, has led many theorists to dismiss the applicability of the 'pillarization' model to the current Indonesian situation. I would argue, however, that the religious pillars have not been eliminated, even though their activities are now more circumscribed. And this emphasis on the 'modern wing' of the church ignores the way in which the church's power has been extended through its inculturation in local tradition. As the 'modern wing' of the church has been weakened, the 'traditional wing' has gained in strength as 'feasting' has been 'bureaucratized'. In this section, I will examine this extension of the church bureaucracy into feasting through an analysis of the creation and extension of the church's Women's Group (Komisi Wanita).

One of the reasons why analysts have dismissed the applicability of the 'pillarization' model in the New Order period is that they conceive 'worship' as a non-political activity. However, I found it necessary to examine worship in terms of 'power-knowledge' relations. ${ }^{28}$ The creation of 'religious knowledge' through the act of preaching simultaneously creates both knowledge and 
deference. The similarity between the Dutch word for minister (dominee) and its cognate, dominate (domineren), is somewhat ironic. In Central Sulawesi, this domination is not achieved through the 'shared beliefs' of the congregation, but through the rationalisation of the application of discipline; the voluntary surrender of a voice within a ritual setting which priories the interpretation of Truth provided by the minister. ${ }^{29}$

It is within the inherent limits of this power relationship that 'problems of meaning' (i.e. local perceptions of sin) develop as the particular interpretations of a preacher are challenged. Many may listen to a minister's injunctions against animist rituals, for example, yet continue to covertly practice them, herice requiring the surveillance of the minister in the fields. Geertz, following Weber, rooted the 'rationalization of belief systems' in such problems which thus demanded a 'sweeping, universal, and conclusive' symbolic resolution. ${ }^{30}$ Among the To Pamona, such problems of meaning have not been met by grand theory, by the inculcation of a 'more convincing' propositional (i.e. theological) knowledge, but with a more refined application of the particularistic 'case study' approach of the mission. That is, rather than attempt to assert control through the inculcation of a coherent set of intellectual beliefs (a theology) which addressed the ultimate 'problems of meaning' (do spirits exist), ministers have instead refined the mechanisms of deference by which their particularistic solutions are definitively reached and the social body disciplined. Phrased somewhat differently, ministers have not addressed problems of meaning though the presentation of more convincing and systematic propositional arguments, but by trying to create a more obedient worshipper willing to defer to the superior opinion of the minister. They have done so by multiplying the number of types and occasions of worship services within which their authority is ritually displayed through feasting.

Religious rationalisation of this type involves the refinement of the church's methods for reforming the self. Preaching called for self-reflection and examination, and voluntary self-reformation. Preaching did not forbid, and hence Weberian definitions of power which stress the repressive aspects of the relationship, 'the probability that one actor within a social relationship will be in a position to carry out his own will despite resistance', obscure the conditions within which voluntary compliance can be fostered. This compliance is encouraged by the structured nature of the ritual occasion which drew on indigenous forms of politeness behaviours to garner deference to the speaker. Further, their words are contextualised and legitimated in terms of the Bible, the recognised source of the Truth, the Word. Thus, the relationship established through preaching is not characterised by one member carrying out their will despite resistance. Rather, the relationship is characterised by the voluntary abandonment of resistance. The relationship is not predicated upon coercion, but hegemony.

This limited power is most effective when it is systematically utilised, when it is part of a sustained disciplinary program which regularly inculcates voluntary deference and thus naturalises it. Resistance calls for a renewal of attempts 
to ensure compliance through further preaching in new situations of conflict. This process of the extension of ministerial discipline can be clearly seen in the church's approach to women. The missions excluded women from positions of authority within the church; hence it should be no surprise that shamans (almost all women) were the initial focal point of traditionalist resistance to the mission. In Tentena, the village shaman refused to convert and continued to hold curing ceremonies until her death in the 1940s. The village minister's response was to encourage her son to enter the ministry over her objections. The son later returned to become the village minister. This selective recruitment of men to positions of power was at once the source of the problem of women's continuing resistance, and the initial attempt to resolve it. By recruiting the son to Christianity, the mother's authority was undermined. Yet this strategy was not totally effective (the shaman never converted), and women remained the 'problematic' repository of animist ceremonies requiring reformation.

It was the perception of women as a problem in the church which led to the formation of the first women's group in Tentena in 1953 by the local minister. The intent of the group was to foster a greater degree of Christian consciousness among the women of the village through educational, health and service programs. ${ }^{31}$ The group's first programs involved weekly religious 'services'. The English word 'service' aptly summarises both aspects of these programs which included worship as well as 'serving' the minister's guests. ${ }^{32}$ The weekly religious services provided these women leaders with their first opportunities to preach on a regular basis. The Women's Group thus became the crucible within which women's authority was melded with a presbyterial bureaucracy, much like the men in the church's governing body. Once the group had established an independent governing body (of women) in 1954, its priority program became a school which taught secretarial skills and enabled its graduates to obtain positions in the civil service. The group also expanded its role and membership in village society through the regularisation of labour exchanges for their members' children's weddings. The group's interest in weddings had no theological rationale; rather, it emerged out of the group's desire to make itself relevant to the culturally constituted needs of members. As one leader put it, 'they were coming to me anyway [to arrange weddings], so I made weddings a Women's Group programme'.

In this way, the normal cycle of social reproduction was subordinated to preaching, thus necessitating a 'voluntary' deference to the leaders who organise these feasts of social reproduction cum religious services. The leader's power is attenuated, not absolute, hence requires a constant renewal; without the constant rounds of feasting, there is no enactment of deference, no power. In turn, the women submitting to the discipline of the Women's Group find that they are subordinating the social reproduction of their families to the demands of the church. The principal demand is that the women submit themselves to the reforming power of the Word. Each ritual of social reproduction is accompanied by a sermon written to fit their circumstances, to address 
their specific sins. The sermon cannot coerce compliance to the ideal 'good Christian life'. The leader of the Women's Group emphasised that they organise the rituals of social reproduction of all families irrespective of the women's participation since the group had a 'responsibility' to ensure the event is correctly performed. This 'responsibility' ensures that all women are subjected to the same discipline, whether they accept it or not. The performance of such a ritual thus combines ideological pressure, the call to attend to the Word, with moral persuasion, the creation of debts of gratitude through the exchange of goods and services which accompany the wedding feast.

The overwhelming success of the Women's Group has effectively reversed the shurch's perception of women as a problem. Today, women outnumber men in participation in all church services. Women candidates consistently garner the largest number of votes in elections for Elders. Women applicants for the theological seminary outnumber men. The church is now attempting to mimic this success with its men and youth groups. The expansion of services is driven by a desire to attack the root causes of 'sin', and thus enable its members to become better Christians. These programs, like the women's groups, frequently emerge through ad hoc measures whose success is emulated by others, until the whole is incorporated in the Presbyterian form of the church. This approach has its roots in the mission's initial radical decision to shift the subject of conversion from the individual to 'culture'. Kruyt's argument was that as To Pamona culture (adat) was Christianised, individual members of To Pamona society would simultaneously be transformed. ${ }^{33}$ The emphasis was placed on institutional transformation as a precursor to individual change.

So far, I have argued that Kruyt's mission to the To Pamona was influenced by the social and cultural processes affecting Dutch Reformed Protestantism at the turn of the century, with the end result that the To Pamona, like Dutch Protestants, were 'pillarized'. Geertz made similar arguments during the Guided Democracy period. But since the New Order reorganisation of the political system, analysts have rejected the applicability of the 'pillarization' model. I argued that the bureaucratisation of the 'traditional wing' of the church, its extension of the use of feasting and worship services to inculcate Christian discipline, needed to be incorporated within the model. Thus, rather than focus on the specifically political aspects of 'pillarization' as in the past, I call here for a redefinition of the problem in terms of the Weberian literature on the 'rationalization of religion'.

As is typical of so many of the enduringly useful concepts in the study of Indonesia, the term aliran (streams, or religious 'pillars') was introduced by Clifford Geertz, although his formulation is not without contradiction. The term was adopted in The Religion of Java (1960), and further refined in Peddlers and Princes (1963) and The Social History of an Indonesian Town (1965). ${ }^{34}$ Geertz's definitions of the term in these three works, and the boundaries he sets between the aliran are not consistent. In the widest sense, as in the Dutch case, aliran are treated as the product of deeply cutting religious 
divisions and their political and social consequences. Alternately, as a structural phenomenon, the course of each 'stream' is directed by a political party which increasingly canalises the ebb and flow of social life into ever more hierarchic and bureaucratic clubs and unions.

Each party with its aggregation of specialized associations provides, therefore, a general framework within which a wide range of social activities can be organized, as well as an over-all ideological rationale to give these activities point and direction. ${ }^{35}$

These two not always compatible definitions give rise to contradictory conceptualisations of the social base of aliran since the overlap of religion and party is not as neat as the model suggests. In his later work, for example, each aliran is said to correspond to one of the four major political parties: the Nationalists, the Communists and the two Muslim parties, Masyumi and the more conservative Nahdatul Ulama. In his earlier formulation, however, aliran are characterised by their religious constituency, not their political affiliations. In The Religion of Java Geertz describes only three aliran: the Muslims santri, the Hindu-Buddhist elite priyayi and the peasant syncretists abangan. Each religious group was given a political voice through one of the political parties noted above: the priyayi by the Nationalists, the santri by the Muslim parties, and the abangan by the Communists.

Rather than critique Geertz for these shifting and contradictory formulations, I would note that a similar confusion is evident in the Dutch literature on 'pillarization'. ${ }^{36}$ Much of this confusion stems from the manner in which these pillars have been conceived as, at once, religious movements and as extensions of political parties. Like Geertz, the Dutch literature places a great deal of importance on the ideological role religion plays in legitimating the activities of specific political parties. The question thus arose, from a structural perspective, are all political parties pillars? or just the religious parties? From a structural point of view, each political party which had its own attendant social clubs and organisations, had to be treated as a pillar. This necessitated the redefinition of religion in the social science literature in an attempt to maintain the integrity of the model. Religion was now defined in 'value-free' terms, as a 'worldview', ignoring the highly politicised social definition of religion in the Netherlands. The developers of this theoretical reformulation, Kruijt and Goddijn describe four Dutch pillars which match the four major political parties, and include both the secular Liberal party and the Socialists. ${ }^{37}$

Geertz also describes four Indonesian 'streams' including the Nationalist Party whose priyayi membership he mistakenly identifies as a religious group, and the Communist party. However, the conceptualisation of religion in terms of worldviews ignores the politically salient, historically specific definitions of religion found in both the Netherlands and Indonesia. In the Netherlands, a radical divide, the antithesis was drawn between the religious parties, associated with organised denominations, and the secular parties, the Liberals 
and Socialists. The divide (antithesis) between the 'religious' and the 'secular' was considered of greater import than denominational divisions within the religious sphere. Similarly in Indonesia the definition of agama, or 'religion' has been constitutionally entrenched and draws a clear line between that which is a proper 'religion' and a mere worldview, kepercayaan. Indonesians conceive neither the Nationalist Party nor the Communists as 'religious' groups.

I would argue that the current formulation of 'pillarization' is misconstrued. What has excited the political scientists and sociologists who developed the 'pillarization' model is the invasion of the political realm by organised religion, a breach as it were, in the otherwise solid bastions of secular modernisation. ${ }^{38}$ Yet, by conceiving religious pillars as a political phenomenon, organised from the top down as a means of mobilising voters, they have equated a selfdefined 'religious' movement, with 'religious' goals, reached by 'religious' means as a mere disguise for power politics. A single political framework is used, pushing square 'religious' pegs in round 'secular' holes, and so producing contradictory definitions of religious pillars as both 'political parties with ancillary religious organizations' and 'religious groups with political facets'. These two conceptualisations are not mirror images of one another. A consequence of this particular formulation in terms of political parties is the view that aliran in Indonesia have disappeared (or that their importance has been marginalised) with the elimination of the Communist party and the restructuring of the Indonesian political system under Suharto's New Order regime. Seen as 'religious groups with political facets', such marginalisation is not so readily evident.

By recasting the discussion of aliran in terms of an alternate literature, that of the rationalisation of religion, we avoid many of these difficulties. 'Rationalization' is a key concept in the sociology of Max Weber (1963), who used the term in multiple senses. ${ }^{39}$ On the one hand, rationalisation was used in reference to an intellectual trend towards the 'disenchantment of the world', the replacement of magical elements of thought with more systematically coherent ideas. ${ }^{40}$ Alternately, rationalisation was used in reference to institutional specialisation and differentiation, and the development of hierarchical, bureaucratic forms of social organisation. ${ }^{41}$ The concept was introduced into the Indonesian literature in a now classic paper by Clifford Geertz. ${ }^{42}$ Geertz described the transformation of Balinese religion from a conceptually disorganised, animist 'hodgepodge of feckless ritual' into a coherent, 'rationalized, self-conscious and worldly-wise' belief system which addresses the eternal 'problems of meaning - evil, suffering, frustration, bafflement, et cetera. ${ }^{43}$ The main force behind the rationalisation of Balinese belief systems was the nobility, who had found their ceremonially based authority challenged by republican ideology. What was once ritual habit unquestioningly supporting noble prerogatives now required its reasons - its doctrines. As Geertz notes, 'to see in all this a mere Machiavellianism however, would be to give the young nobles both too much credit and too little. Not only are they at best partially conscious of what they 
are doing, but, like my village theologians, they too are at least in part religiously rather than politically motivated'. ${ }^{44}$ The rationalisation of the belief system was thus accompanied by the reorganisation of the Balinese nobility, and the Brahmana caste in particular, within the rational bureaucratic order of the republican state. The rationalisation of Balinese Hinduism under the auspices of the 'Balinese Ministry of Religion' has regularised the qualifications of Brahmana priests, classified temples, and established a training school and 'even a small religious political party centered around a ranking noble and dedicated to forwarding these changes'. ${ }^{45}$

Easy parallels can be drawn between the class composition and activities of this religious rationalisation of Balinese religion with its attendant creation of a political wing, the formation of Islamic aliran in Java, and the religious revival (Reveil) which swept the Dutch aristocracy during the 1850s, giving birth to the Orthodox Calvinist Anti-Revolutionary Party. ${ }^{46}$ Yet my point is that these cases of religious rationalisation have the structural effect of creating religious aliran/pillars. Geertz, surprisingly, does not himself draw the parallel between the rationalisation of Balinese religion and aliran formation. ${ }^{47}$ In focusing upon the emotional and attitudinal changes associated with rationalisation as an autonomous cultural process, Geertz ignores one half of Weber's original formulation which clearly placed the rationalisation of beliefs in the context of the bureaucratisation of religious establishments. This Weberian rationalisation of Balinese religion, prompted as much by proximate issues of national religious politics and changing patterns of local authority as by the perennial problems of meaning, was as much social-organisational as it was a systemisation of doctrine. ${ }^{48}$

The growing literature which has emerged out of Geertz's pioneering work, has fastidiously addressed this one-side interpretation of the processes of rationalisation. Similar cases of the self-conscious rationalisation of belief systems' (kepercayaan) as worldly-wise religions (agama) have been described among numerous groups in the Outer Islands since Geertz's article first appeared in 1964. Religious transformations have been described among the Ngaju Dayaks ${ }^{49}$ and the Meratau ${ }^{50}$ of Kalimantan (Borneo), the Tenggar of highland Java, ${ }^{51}$ and among the Sa'dan Toraja ${ }^{52}$ and To Wana ${ }^{53}$ of Sulawesi. These examples have all drawn attention to the 'politics of agama', and rooted the rationalisation of animist traditions in the political demands of the New Order government's civil religion. This literature is, however, a diversion from the parallel I wish to emphasise between rationalisation and aliran formation.

While the literature on the 'politics of agama' has sought to underscore the social roots of religious rationalisation, it implicitly accepts that only 'irrational' animist traditions can be 'rationalized'. The literature thus focuses upon the still animist, isolated groups (suku terasing) of the Outer Islands, rather than upon the followers of world religions in the Javanese heartland who are incorporated within aliran. While this literature has sought to ground religious rationalisation in social and political processes, its static view of the end state towards which their ethnographic subjects are working prevents parallels being 
drawn with the 'already rational' world religions. ${ }^{54}$ The aliran of Java are treated as static social structures, not as a dynamic religious process comparable to the transformations undergone by those 'who do not yet have a religion' (orang yang belum beragama).

Applying the rationalisation model to world religions requires that we address the constellation of power and knowledge which defines the boundaries of 'religiosity' in both Indonesia and the Netherlands. Although both Christianity and Islam have a well developed 'already rational' theological corpus, the institutional processes by which this knowledge is created and perpetuated continues to change, develop and extend into civil society. This is what Foucault referred to as the 'micro-physics' of modern forms of power/knowledge. ${ }^{55}$ A 'rationalizing' religion, like any other bureaucratising institution, seeks to reorganise the social life of its subjects through the internalisation of "normalizing' disciplinary practices whose power lies in the ways in which they mask how they work. It is these disciplinary practices which are rationalised as a means of extending their relations of colonising power and in so doing, they create a religious pillar. These hegemonic discourses, although ideally totalising, are not the product of a top-down political conspiracy. Rather, the rationalisation of these disciplinary techniques emerges in the niches, where they are successfully challenged and hence call forth a renewed reformist effort to deal with the problem of 'sin'.

This 'internal conversion' can be contrasted with that sparked by state demands, as described in the broad 'politics of agama' literature. Although not explicitly 'political', this process of 'internal conversion' takes place in the context of state policies which shape and mold the public role which religious organisations may legitimately assume. This results in the creation of a public discourse on 'religiosity' in which particular ritual traditions demonstrate the appropriateness of their receiving state sanction and resources. While the two processes are related, they are not necessarily complementary. That is, 'internal conversion' and the creation of a religious pillar extend the hegemony of religious bureaucracies, a hegemony that may be threatened by the state and its attempts to control those bureaucracies. Religious pillars may thus become the locus of resistance to the state, the situation found historically in the Netherlands, and currently in Indonesia.

We should be not be surprised that religious rationalisation, no less than development processes such as 'agricultural involution', can be rooted in colonial state formation. Religious rationalisation is not, however, the product of a particularly colonial process; both Indonesia and the Netherlands itself were pillarised in the early twentieth century by a similar 'apartheid of souls'. I have argued that rationalisation had a dual effect; on the one hand, there was the rationalisation of 'belief systems' which emerged out of the definitional debate with the liberal state on the essence of 'religion'. Rationalisation in this one sense is tied to the liberal state's modernist desire to sever religion from politics, to cut the parochial link between religion and local communities so as to foster the 'disenchantment of the world' necessary for secular gov- 
ernance. Rationalisation in this narrow sense has recently sparked a wave of religious transformations among the animist fringe of the Outer Islands. Similarly, it transformed Christianity and Islam in the heartland of colonial rule.

Since the New Order, Dutch and Indonesian paths have diverged. It should be fairly clear that the New Order's attempts to depoliticise parliament have removed effective decision-making power from elective offices and vested them in the state itself. The New Order is driven, in other words by impulses towards statism, centralisation and uniformity. ${ }^{36}$ The ideal to which their political policies are working would appear to be a variation of one party rule in which the 'diversity' of Indonesian 'functional groups' (political interests) would be molded into 'unity' through particularly Javanese cultural (non-political) values of consensus building (musyawarah) and 'benevolence-obedience' as embodied in the Pancasila. In this ideal formation, effective executive power would lie with a strong president, the dispenser of benevolence, and the kinglike centre from which direction would flow. One could argue, in other words, that the New Order is seeking to establish itself as the sole legitimate aliran.

However, the hegemony of the state can never be complete. As my discussion of the institutional development of the Christian Church of Central Sulawesi has shown, worship services do establish and maintain 'non-political' political relations outside the official purview of the state. It this situation is no simple matter to 'render unto Caesar the things which are Caesar's; and unto God the things that are God's'. The overlap in bureaucratic competencies fostered by the Dutch Protestant mission of Albert C. Kruyt has made 'culture' a domain of contestation between church and state. And the success of the church in defining To Pamona ethnic identity in terms of Christianity is an indication of the continuing relevance of the 'pillarization' model. As the surviving locus of political resistance to the state, and with an established history of political mobilisation, it is thus to these aliran that we should turn as Indonesia makes a few faltering steps towards democratisation. 


\section{Notes}

1 This article appeared earlier as 'Pillars of Faith: Religious Rationalization in the Netherlands and Indonesia', in Documentatieblad voor de Geschiedenis van de Nederlandse Zending en Overzeese Kerken 7/1 (2000) 1-23.

2 Th. van den End, 'Rencana Gereja Kesatuan Sulawesi Tengah pada Masa Zending' in: Pdt. Dj. Tanggerahi et al. eds, Wajah GKST (Tentena 1995); A. Schrauwers, 'Returning to the "Origin": Church and State in the Ethnogenesis of the "To Pamona"' in: Joel Kahn ed., Southeast Asian Identities: Culture and the Politics of Representation in Indonesia, Singapore, Malaysia and Thailand (Singapore, New York, London 1998).

3 S.C. Graaf van Randwijck, Handelen en Denken in Dienst der Zending: Oegstgeest 1897 1942 (The Hague 1981) 146-149.

4 A. Schrauwers, book in press; D. Henley, Nationalism and Regionalism in a Colonial Context: Minahasa in the Dutch East Indies (Leiden 1996).

5 J.P. Kruijt and Walter Goddijn, 'Verzuiling en Ontzuiling als Sociologisch Proces' in: A.J.N. Hollander et al. eds, Drift en Koers: Een halve eeuw sociale verandering in Nederland (Netherlands 1968); S. Stuurman, Verzuiling, Kapitalisme en Patriarchaat: Aspecten van de Ontwikkeling van de Moderne Staat in Nederland (Nijmegen 1983).

6 B.S. Harvey, Permesta: Half a Rebellion (Ithaca 1970) 27.

7 B. Gunawan and O.D. van den Muizenberg, 'Verzuilingstendenties en Sociale Stratificatie in Indonesië', Sociologische Gids 14 (1967); B. Gunawan, 'Aliran en Sociale Structuur' in: W.F. Wertheim ed., Buiten de Grenzen (Netherlands 1971); R.T. McVey, 'Nationalism, Islam, and Manism: The Management of Ideological Conflict in Indonesia' in: Ruth McVey ed., Nationalism, Islam, and Marxism (Ithaca 1971); W.F. Wertheim, 'From Aliran towards Class Struggie in the Countryside of Java' in: W.F. Wertheim ed., Dawning of an Asian Dream: Selected Articles on Modernization and Emancipation (Amsterdam 1973); J.S. Kahn, 'Ideology and Social Structure in Indonesia', Comparative Studies in Society and History 20/1 (1978).

8 N. Ali-Fauzi ed., ICMI: Antara Status Quo dan Demokratisasi (Bandung 1995).

9 (Noorduyn 1991).

10 Henley, Nationalism and Regionalism, 143.

$11 \mathrm{~J}$. van Goor, 'Imperialisme in de Marge?' in: J. van Goor ed., Imperialisme in de Marge: De Afronding van Nederlands-Indië (Utrecht 1986); M. Kuitenbrouwer, The Netherlands and the Rise of Modem Imperialism: Colonies and Foreign Policy, 1870-1902 (New York 1991).

12 (Arts 1985: 101).

13 Randwijck, Handelen en Denken, 658.

14 (Kruyt 1895-97, Kruyt and Adriani 1912-4, Adriani 1919, Kruyt 1950).

15 (Kruyt 1906, Adriani 1919).

16 (Kruyt 1894, Adriani 1928).

17 (Adriani 1931).

18 (See the bibliographies in K.J. Brouwer, Dr. Albert Kruyt, Dienaar der Toradja (The Hague 1951) 91; Adriani 1932).

19 A.C. Kruyt, Zending en Volkskracht (The Hague 1936) 48, my translation.

20 A.C. Kruyt, Van Heiden tot Christen (Netherlands 1925) 134-157.

21 (Adriani 1932 II: 183).

22 (Adriani 1932 I: 369).

23 J. Kruyt, Het Zendingsueld Poso (1970) 359-372.

24 Ibid., 312.

25 Ibid., 313.

26 (Keeler 1987: 142-57).

27 Woodward 1989: 52).

28 M. Foucault, Discipline E Punish: The Birth of the Prison (New York 1979) 27.

29 Cf. M. Bloch, 'Symbols, Song, Dance and Features of Articulation: is Religion an extreme form of traditional authority?', Archives of European Sociology 15 (1974) 55-81. 
30 C. Geertz, "Internal Conversion" in Contemporary Bali' in: The Interpretation of Culture (New York 1973) 173.

31 C. Lumentut, Kedudukan Wanita Dalam GKST (Indonesia 1991) 28-29.

32 Persatuan lbu Kristen Tentena, Sejarah Berdirinya PIK GKST Cabang Tentena (Indonesia 1985) 2.

33 Kruyt, Zending en Volkskracht.

34 C. Geert, The Religion of Java (Chicago 1960); Peddlers and Princes: Social Development and Economic Change in Two Indonesian Towns (Chicago 1963); The Social History of an Indonesian Town (Cambridge 1965).

35 Geertz, Peddlers and Princes, 15.

36 Stuurman, Verzuiling, Kapitalisme, 62-66.

37 Kruijt and Goddijn, 'Verzuiling en Ontzuiling'.

38 A. Lijphart, Verzuiling, Pacificatie en Kentering in de Nederlandse Politiek (Amsterdam 1968); Kruijt $\varepsilon$ Goddijn, 'Verzuiling en Ontzuiling.'

39 M.G. Peletz, 'Sacred Texts and Dangerous Words: The Politics of Law and Cultural Rationalization in Malaysia', Comparative Studies in Society and History 35/3 (1993) 66-7.

40 Max Weber, The Sociology of Religion, Ephraim Fischoff ed., Introduction by Talcott Parsons (Boston 1963) 10.

41 Ibid., 30-31.

42 Geertz, 'Internal Conversion'.

43 Ibid., 172.

44 lbid., 186.

45 Ibid., 189.

46 A.J. Rasker, De Nederlandse Hervormde Kerk Vanaf 1795: Haar Geschiedenis en Theologie in de Negentiende en Twintigste Eeuw (Kampen 1974) 75; Michael Wintle, 'Pillars of Piety: Religion in the Netherlands in the Nineteenth Century', Occasional Papers in Modern Dutch Studies 2 (1987) 22.

47 Geertz, Social Development, 10.

48 J.M. Atkinson, 'Religions in Dialogue: The Construction of an Indonesian Minority Religion', American Ethnologist 10/4 (1983).

49 J.A. Weinstock, "Kaharingan: Borneo's "Oldest Religion" Becomes Indonesia's Newest Religion', Borneo Research Bulletin 13/1 (1981); 'Kaharingan: Life and Death in Southern Borneo' in: Rita S. Kipp and Susan Rodgers eds, Indonesian Religions in Transition (Tucson 1987); A. Schiller, Small Sacrifices: Religious Change and Cultural Identity among the Ngaju of Indonesia (Oxford 1997).

50 A.L. Tsing, 'A Rhetoric of Centres in a Religion of the Periphery', Indonesian Religions.

51 R.W. Hefner, 'Ritual and Cultural Reproduction in Non-Islamic Java', American Ethnologist 10/4 (1985); 'The Political Economy of Islamic Conversion in Modern East Java' in: William Roff ed., Islam and the Political Economy of Meaning: Comparative Studies of Muslim Discourse (Berkeley 1987).

52 E. Crystal, 'Cooking Pot Politics: A Toraja Village Study', Indonesia 18 (1974); T.A. Volkman, 'Mortuary Tourism in Tana Toraja', Indonesian Religions; R. Waterson, Ritual and Belief among the Sa'dan Toraja (Canterbury 1984).

53 Atkinson, 'Religions in Dialogue'.

54 For exceptions see Hefner, 'Political Economy of Islamic Conversion'; J.R. Bowen, Muslims through Discourse: Religion and Ritual in Gayo Society (Princeton 1993).

55 Foucault, Discipline $E$ Punish, 26.

56 R.W. Liddle, Leadership and Culture in Indonesian Politics (Sydney 1996) 81. 